\title{
DIDAKTIČKE SMJERNICE ZA IMPLEMENTACIJU KURIKULUMA MEĐUPREDMETNE TEME »ODRŽIVI RAZVOJ«U PREDMETNE KURIKULUME
}

\author{
Gabrijela Marin \\ Medicinska škola Ante Kuzmanića, \\ Zadar, Hrvatska \\ gabrijela.marin@skole.hr
}

Primljeno: 1. 9. 2020.

\begin{abstract}
Održivi razvoj kao koncept promjena koji je usmjeren stvaranju okruženja u kojemu pojedinac živi u suglasju s prirodom je imperativ kojemu moramo težiti. U posljednjih dvadesetak godina, unatoč zakonskoj regulativi, implementacija tema održivog razvoja u nastavne programe bila je sporadična, prihvaćena od strane ekološki senzibiliziranijih nastavnika, a realizirana najčešće kroz projektne aktivnosti. Iako se kurikularnom reformom održivom razvoju priznala važnost kroz uvođenje međupredmetne teme »Održivi razvoj«, realizacija odgojno-obrazovnih očekivanja je upitna. Upravo konceptualna složenost novoga kurikuluma koja se temelji na interdisciplinarnosti podrazumijeva mnogo širi spektar znanja $i$ vještina od onoga što je jedan nastavnik stekao formalnim obrazovanjem. Cilj je ovoga rada iznijeti pregled najznačajnijih događaja u povijesti obrazovanja za održivi razvoj u Republici Hrvatskoj te na temelju istraživanja hrvatskih i stranih autora izdvojiti didaktičke smjernice koje će nastavnicima olakšati implementaciju novoga kurikuluma u njihovom predmetu, a koje se odnose na izbor sadržaja, korištenje strategija učenja i poučavanja te vrednovanje.
\end{abstract}

Ključne riječi: održivi razvoj, odgoj i obrazovanje za održivi razvoj, kompetencije nastavnika, strategije učenja i poučavanja, međupredmetne teme

\section{Uvod}

Nalazimo se u vremenu kada je održivi razvoj kao program promjena i kao koncept razvoja suvremenog društva konačno prepoznat 
kao jedini mogući model opstanka čovjeka na planeti Zemlji. I dok je sedamdesetih godina 20. stoljeća mnogima pojam održivog razvoja bio tek pokret pojedinaca koji su bili ekološki osviješteni, javno obraćanje tinejdžerke Grete Thunberg pred zastupnicima Europskog parlamenta i Ujedinjenih naroda 2019. godine pokazalo je da je došao trenutak u kojemu je nestala granica između osobne i kolektivne odgovornosti, između lokalnog i globalnog, između danas i sutra.

Nesigurnost koju danas osjeća svaki stanovnik Zemlje u trenutku pandemije koronavirusom dokazuje kako je unatoč velikom napretku tehnologije čovjek nemoćan pred genomom virusne čestice veličine svega nekoliko nanometara. Očigledno je da nove generacije treba pripremiti na svijet koji je dinamičan i podložan promjenama, u kojemu je svaki organizam jednako važan i u kojemu je odgovornost prema sebi, drugima i prirodi pitanje opstanka naše civilizacije.

Da bi se skrenula pozornost svjetske javnosti na iznimno važnu ulogu obrazovanja za ostvarivanje održivosti, Ujedinjeni narodi proglasili su razdoblje od 2005. do 2014. godine desetljećem obrazovanja za održivi razvoj. Iako je Republika Hrvatska kao samostalna država sudjelovala na dvije značajne konferencije na svjetskoj razini - 1992. godine u Rio de Janeiru i 2002. godine u Johannesburgu - značajniji pomak u hrvatskom zakonodavnom okviru događa se tek 2009. godine. Strategija održivog razvitka Republike Hrvatske (NN, 30/2009) kao krovni dokument među ostalim naglašava koliko je važno podići obrazovnu razinu svih građana i graditi društvo temeljeno na znanju te podupirati kulturu istraživanja i ulaganja u razvoj. Promjena u obrazovanju budućih generacija podrazumijeva sustavno i cjelovito planiranje pa su tijekom summita o održivom razvoju, 25. rujna 2015. godine u New Yorku, države članice Ujedinjenih naroda usvojile Program globalnog razvoja do 2030. godine (tzv. Agenda 2030), prema kojem:

»... do 2030. godine treba osigurati da svi učenici steknu znanja i vještine potrebne za promicanje održivog razvoja, uključujući kroz obrazovanje za održivi razvoj i održivi stil života dodatno i ljudska prava, ravnopravnost spolova, promicanje kulture mira i nenasilja, globalno građanstvo i uvažavanje kulturne raznolikosti te doprinosa kulture održivom razvoju.« (UN, 2015, 21)

U međuvremenu su se pronalazila različita rješenja, ali unatoč individualnim naporima nastavnika teme održivog razvoja najčešće su 
realizirane ili kao projektni zadatci u školi ili kroz aktivnosti izvanučioničke nastave. Iako se kurikularnom reformom, koja je započela školske godine 2019./2020., održivom razvoju priznala važnost uvođenjem međupredmetne teme »Održivi razvoj«, realizacija odgojno-obrazovnih očekivanja novoga kurikuluma je i dalje predmet rasprava u nastavničkim zbornicama. Glavni razlog tome je to što implementacija ovoga kurikuluma podrazumijeva mnogo širi spektar znanja i vještina od onoga što je jedan nastavnik u predmetnoj ili razrednoj nastavi stekao formalnim obrazovanjem.

Cilj ovoga rada je iznijeti pregled najznačajnijih događaja u povijesti obrazovanja za održivi razvoj u Republici Hrvatskoj te na temelju istraživanja hrvatskih i stranih autora izdvojiti didaktičke smjernice koje će nastavnicima olakšati implementaciju kurikuluma međupredmetne teme u njihovom predmetu.

\section{Odgoj i obrazovanje za održivi razvoj u Republici Hrvatskoj}

»Održivi razvoj je takav razvoj koji omogućuje zadovoljavanje potreba u sadašnjosti, bez ugrožavanja mogućnosti budućih generacija da i one zadovoljavaju svoje potrebe.« (Garašić, 2011, 14)

Ova definicija održivog razvoja kao novoga, univerzalnog pojma, objavljena je 1987. godine od strane Svjetske komisije za okoliš i razvoj. U ostvarivanju ciljeva održivog razvoja najveću ulogu ima obrazovanje što je rezultiralo sintagmom 'obrazovanje za održivi razvoj' (OOR). Obrazovanje za održivi razvoj je obrazovanje za život svakog pojedinca koji je u svakodnevnoj interakciji sa svojim okolišem. Zbog toga se, prema Garašić $(2011,26)$, ono treba provoditi na tri razine: formalnim obrazovanjem u nastavnim institucijama, izvan uobičajenih obrazovnih ustanova i putem medija. U okvirima formalnog obrazovanja u posljednjih dvadesetak godina implementacija tema održivog razvoja u nastavne planove i programe obrazovnih djelatnika bila je sporadična, prepuštena entuzijazmu pojedinih nastavnika. Iako su pedagozi i metodičari navodili smjernice $u$ vidu prijedloga sadržaja i aktivnosti po nastavnim predmetima (De Zan, 2000; Uzelac et al., 2014) izostala je sustavna implementacija kroz čitavu vertikalu odgojno-obrazovnog sustava. S druge strane, ideja o izdvajanju sadržaja održivog razvoja u 
zaseban predmet odbačena je zbog važnosti interdisciplinarnog pristupa u poučavanju. S tim u vezi prije desetak godina Previšić upozorava:

$» \mathrm{U}$ godinama koje dolaze ne smijemo se dovesti u situaciju da obrazovanje za održivi razvoj postane još jedan uobičajeni nastavni predmet kojega će učenici vrlo brzo zamrziti, a nastavnici se prema njemu odnositi rutinski i birokratski.« (Previšić, 2008, 59-60)

Iako se u nastavnim planovima i programima iz 2006. godine (MZOŠ, 2006) u poglavlju »Integrativni odgojno-obrazovni sadržaji« navodi »Odgoj i obrazovanje za okoliš i održivi razvoj«, bitan preokret u obrazovnoj politici Republike Hrvatske nastaje donošenjem Nacionalnog okvirnog kurikuluma za predškolski odgoj i obrazovanje te opće obvezno i srednjoškolsko obrazovanje (MZOŠ, 2010) koji je rađen s osloncem na Europski referentni okvir ključnih kompetencija za cjeloživotno učenje (EU, 2008). Nedugo nakon toga, 2012. godine, kao odgovor na potrebu jačanja građanskih kompetencija donosi se Kurikulum građanskog odgoja i obrazovanja, GOO (MZOŠ, 2012) s izdvojenim posebnim ishodima učenja ili postignućima učenika od početka osnovne škole do drugog razreda srednje škole, kroz četiri razvojna odgojno-obrazovna ciklusa. U međuvremenu su objavljene i distribuirane različite brošure i priručnici kao pomoć nastavnicima/razrednicima u realizaciji navedenih ishoda.

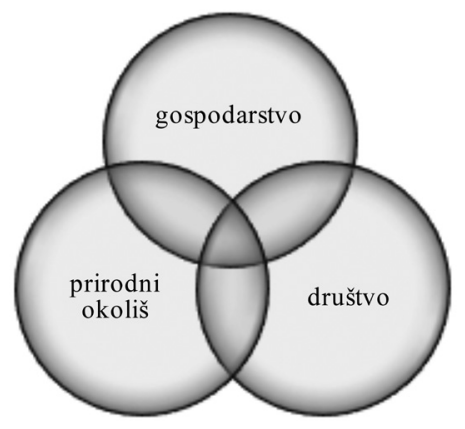

Slika 1. Tri komponente održivog razvoja

Koncept održivog razvoja iznimno je kompleksan jer obuhvaća tri jednako vrijedne i međusobno prožete komponente: socijalnu, ekonomsku i ekološku (Slika 1). Upravo konceptualna složenost rezultirala je izdvajanjem sadržaja održivog razvoja iz Kurikuluma Građanskog od- 
goja i obrazovanja te uvođenjem međupredmetne teme pod nazivom Održivi razvoj.

Prema Odluci o donošenju kurikuluma za međupredmetnu temu Održivi razvoj za osnovne i srednje škole u Republici Hrvatskoj (MZO, 2019) novi kurikulum donosi temeljito razrađena odgojno-obrazovna očekivanja te jasne preporuke za njihovo ostvarivanje na obaveznim i izbornim predmetima, satu razrednika, integriranoj nastavi, u sklopu projekata, izvanučioničkoj nastavi, terenskoj nastavi i izvannastavnim aktivnostima uz povezanost s ostalim međupredmetnim temama i područjima kurikuluma. Interdisciplinarni pristup podrazumijeva ostvarivanje elemenata obrazovanja za održivi razvoj u sklopu svih odgojno-obrazovnih područja. Odgojno-obrazovna očekivanja definirana su na razini ciklusa, kroz tri domene (Slika 2), a razrađuju se kroz pripadajuća znanja, vještine i stavove. Pojedina očekivanja u kurikulumu Održivoga razvoja slična su ili se preklapaju s očekivanjima drugih međupredmetnih tema i nastavnih predmeta, što znači da se nekim aktivnostima može istodobno ostvariti više odgojno-obrazovnih očekivanja $\mathrm{i}$ ishoda.

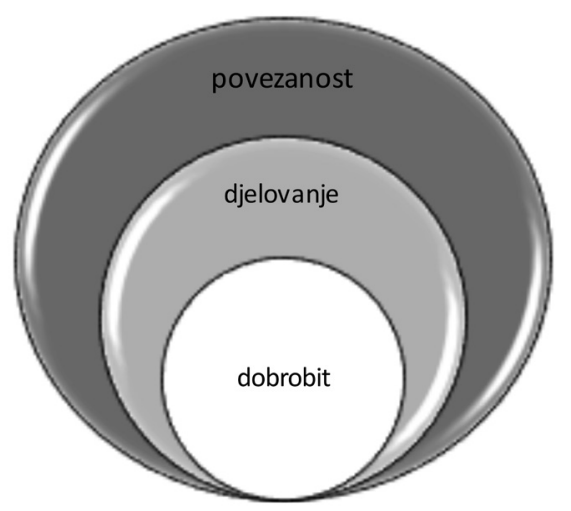

Slika 2. Domene u organizaciji kurikuluma međupredmetne teme Održivi razvoj (NN, 7/2019)

\section{Kompetencije nastavnika}

Planiranje, realizacija i evaluacija ostvarenosti odgojno-obrazovnih očekivanja međupredmetne teme Održivi razvoj najvećim dijelom ovisi o kompetencijama jednog i/ili više nastavnika. Osim specifičnih 
znanja i vještina, ako žele zadržati vjerodostojnost, nastavnici i sami trebaju biti modeli učenja koji će biti primjer društveno odgovornog pojedinca. Ova zadaća, nimalo jednostavna, ukazuje na potrebu definiranja potrebnih kompetencija. Međutim, unatoč pažljivo razrađenim domenama i očekivanjima međupredmetne teme Održivi razvoj, radna skupina u kurikulumskom dokumentu nije definirala potrebne kompetencije nastavnika.

U Kurikulumu građanskog odgoja i obrazovanja (MZOS, 2012) posebno poglavlje odnosi se kompetencije koje trebaju imati nastavnici da bi promovirali demokratske vrednote kroz metode aktivnog i suradničkog učenja i poučavanja. Kompetencije se odnose na pet stručnih područja: opća profesionalna znanja i vještine, strukovna znanja i vještine u području GOO, procesi učenja i poučavanja koji vode razvoju aktivnog i odgovornog građanstva, metode učenja i poučavanja GOO te metode vrednovanja i samovrednovanja u GOO (MZOS, 2012, 11).

U području Obrazovanja za održivi razvoj nekoliko autora izdvaja kompetencije koje nastavnici i svi koji poučavaju o održivom razvoju trebaju razviti. Izobrazba treba biti sadržajna, metodička, socijalno-komunikacijska i personalna (Husanović-Pejnović, 2011). Prema Garašić (2011, 59-60), ključne kompetencije nastavnika u obrazovanju za održivi razvoj su: poznavanje tematike, empatija, spremnost na suradnju - timski rad, kreativnost, motiviranost i organizacijske vještine. Ipak, najpotpuniji opis daje Vukelić (2020) koja kompetencije nastavnika promatra kroz njihov vlastiti vrijednosni sustav i kaže:

»Provedba obrazovanja za održivi razvoj ovisi o njihovim vrijednostima, stavovima, znanju i ponašanju spram održivog razvoja, njihovim obrazovnim filozofijama i stavovima prema poučavanju i učenju, o njihovoj samoprocjeni vlastite efikasnosti u kontekstu ovladanosti kompetencijama nužnima za implementaciju obrazovanja za održivi razvoj.«(Vukelić, 2020, 141)

Dosadašnja istraživanja provedena u Hrvatskoj pokazuju da unatoč pozitivnim stavovima većine nastavnika o važnosti sadržaja održivog razvoja u obrazovanju većina nastavnika smatra kako nisu dovoljno ili su samo djelomično educirani za poučavanje učenika (Borić et al., 2008; Vukobratović, 2017; Vinković, 2018; Horvat, 2018; Vukelić, 2020). Slična situacija prisutna je i u drugim zemljama Europske unije. Istraživanje o potrebnim znanjima u obrazovanju za održivi razvoj, provedeno na uzorku od 337 poljskih nastavnika, pokazalo je da su 
nastavnici nedovoljno pripremljeni za provedbu teza iz područja obrazovanja za održivi razvoj u obrazovne programe. Zanimljivo je da su veća znanja i interes pokazali nastavnici poljskog jezika, stranih jezika, humanističkih i društvenih znanosti u odnosu na biologe, geografe, matematičare i kemičare. Može se pretpostaviti da nastavnici prirodnih znanosti vjerojatno zanemaruju opće principe obrazovanja za održivi razvoj tako što se u svome poučavanju ograničavaju samo na određene aspekte obrazovanja za okoliš (Mróz, Tomczyk, 2018). Neujednačenost nastavničkih strategija potvrdilo je i istraživanje na međunarodnoj razini u 18 država koje inače ostvaruju visoke rezultate na PISA natjecanjima, a u čijim se zaključcima naglašava važnost sustavnog stručnog usavršavanja nastavnika (Laurie et al., 2016).

Kako bi nastavnici mogli kvalitetno educirati svoje učenike o održivom razvoju, nužno je osigurati edukaciju nastavnika u sustavu visokog školstva. Istraživanje u kojemu su uspoređeni nastavni programi učiteljskih studija svih učiteljskih fakulteta u Republici Hrvatskoj pokazalo je još uvijek nedovoljnu količinu nastavnih sadržaja koji bi dali temelj za razvoj potrebnih znanja i nužnih kompetencija nastavnika u obrazovanju za održivi razvoj (Kostović-Vranješ, 2016), odnosno još uvijek ne postoji jedinstveni kurikulum obrazovanja nastavnika (Tatković et al., 2015). Do sličnih rezultata došlo se i pri ispitivanju prirodoslovne pismenosti nastavnika prirode i biologije, različitih godina radnog iskustva, koje je pokazalo da se većina ispitanika osjeća djelomično kompetentnima odnosno da su navedenu kompetenciju tijekom inicijalnog obrazovanja stekli djelomično (Kolar, 2019). Iz svega proizlazi da se obrazovanje za održivi razvoj ne provodi sustavno, već prvenstveno ovisi o osposobljenosti nastavnika da sadržaje kurikuluma integrira $u$ aktualne predmetne kurikulume.

$\mathrm{Na}$ kraju, u skladu s novom paradigmom učenja i poučavanja važno je istaknuti metodičke kompetencije koje se odnose na individualizirani pristup pri realizaciji odgojno-obrazovnih očekivanja međupredmetne teme. Naime, tijekom planiranja i moderiranja procesa učenja i poučavanja nastavnik treba procijeniti individualne potrebe učenika, razinu predznanja, sklonosti i sposobnosti. Ako je riječ o nižoj dobi, svako dijete u skladu s preferiranim stilom učenja može sudjelovati u određenoj ekološkoj aktivnosti i izvršiti određeni zadatak (Lane, Rossov, 1993, prema Uzelac, Starčević, 1999). Naročito je važno pri planiranju 
aktivnosti predvidjeti aktivnosti za učenike s poteškoćama i darovite učenike. Upravo sadržaji održivog razvoja nude mogućnost diferencijacije i individualizacije koja se danas postavlja kao imperativ pedagogije uspjeha za sve. Poštivanje različitih interesa i sposobnosti onih koji uče zahtijeva raznolikost u izboru sadržaja, raznolikost strategija učenja i poučavanja te raznolikost metoda vrednovanja.

\section{Didaktičke smjernice za realizaciju kurikuluma međupredmetne teme Održivi razvoj}

U skladu s ciljevima poučavanja i učenja međupredmetne teme Održivi razvoj, jasno je da proces poučavanja i učenja sadržaja ovoga kurikuluma nije pod ingerencijom samo jednog nastavnika i njegovih kompetencija. U realizaciji aktivnosti poželjna je suradnja različitih dionika, odnosno predlažu se aktivnosti koje podrazumijevaju vertikalnu i horizontalnu prohodnost uz suradnju sa stručnjacima različitih profila. U poglavlju novoga kurikuluma koje se odnosi na učenje i poučavanje u tom se kontekstu navode posjeti gospodarskim subjektima, institucijama i organizacijama koje podržavaju održivi razvoj. Također se potiču gostujuća/pozvana predavanja u školama radi unapređivanja suradnje zajednice sa školom.

Glavni problemi koji se mogu javiti u obrazovanju za održivi razvoj su: nedostatna nova znanja, nepovezanost segmenata i sektora odgoja i obrazovanja za održivi razvoj, nedostatna prisutnost sadržaja u predmetnim kurikulumima te nepovezanost i neaktualnost postojećih sadržaja (Miočić, 2017, 127). Kvalitetno obrazovanje podrazumijeva definirane kriterije kvalitete. U odgoju i obrazovanju za održivi razvoj kriteriji kvalitete mogu se podijeliti u tri osnovna područja, a prema Garašić $(2011,28)$ vezani su uz: kvalitetu poučavanja i procese učenja, politiku škole i organizaciju rada te odnose škole s vanjskim čimbenicima. Kada razmatra područje kvalitete poučavanja i učenja, Garašić ističe:

»Proces poučavanja i učenja stavlja učenika u središte svih aktivnosti uvažavajući kontekst u kojem učenici mogu razvijati svoje ideje, vrijednosti te razumijevanje i promišljanje životne stvarnosti. Budući da su pitanja vezana uz održivi razvoj često kontroverzna i komplicirana, važno je znati kako riješiti sukobe i kompleksne situacije. Obrazovanje za održivi razvoj može se provesti tijekom poučavanja odgovarajućih područja različitih nastavnih 
predmeta, uz naglašene praktične implikacije za učenički svakodnevni život i njihovo neposredno okruženje - lokalnu zajednicu.« (Garašić, 2011, 29)

Naravno, ne smije se zanemariti ni odgojna dimenzija takvih aktivnosti. Odgoj za okoliš je najučinkovitiji ako njegova realizacija prolazi kroz četiri faze: razinu emocija, činjenica, svijesti i djelovanja, odnosno ako se tome pristupi cjelovito, uvažavajući sve aspekte razvoja djeteta (De Zan, 2000).

\subsection{Izbor sadř̆aja}

Sadržaji kurikuluma međupredmetne teme Održivi razvoj određeni su u skladu s tri domene na razini svakog ciklusa kao obvezni i/ili preporučeni sadržaji (Prilog 1). Izbor sadržaja u svakom ciklusu usklađen je s dobi učenika i kurikulumima drugih nastavnih predmeta i međupredmetnih tema. Većina navedenih sadržaja proizlazi iz tema predloženih u općoj strategiji UNESCO (UNESCO, 2005). Na slici 3 se nalazi skraćeni i pojednostavljeni popis tema iz navedene strategije.
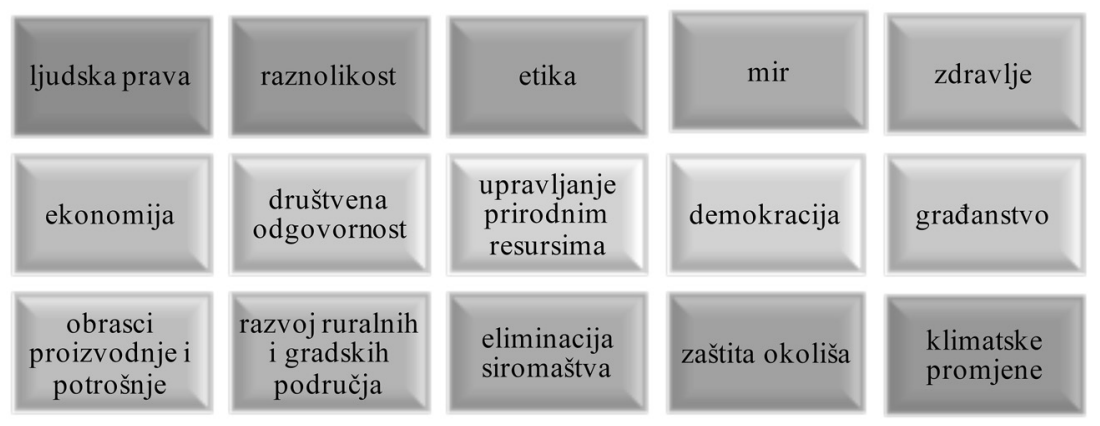

Slika 3. Popis tema u obrazovanju za održivi razvoj (prema Garašić, 2011, 22).

Odabir tema koje će se realizirati kroz školske aktivnosti iznimno je važan jer će na odabranim primjerima učenici steći znanja, razviti vještine i oblikovati stavove. Tema obrazovanja za održivi razvoj mora biti: središnja i/ili globalna tema za održive procese razvoja, mora biti tema s dugoročnijim značenjem, imati kao podlogu diferencirano zna- 
nje i pokazivati što je moguće veći potencijal za djelovanje (prema Gerhard de Haan et al., Garašić, 2011, 20).

Pregledom sadržaja nekadašnjih nastavnih planova i programa (MZOŠ, 2006) uočava se da su teme održivog razvoja u osnovnoj školi očekivano najviše zastupljene u nastavi geografije (Hrgović, 2019). U novom predmetnom kurikulumu Geografije (MZO, 2019a) održivom razvoju priznata je velika važnost na način da jedan od četiri koncepta kurikuluma nosi naziv »Održivost«. Geografija je znanstvena disciplina u interdisciplinarnim područjima znanosti zbog čega se i njezini koncepti formiraju u odnosu na makrokoncepte prirodoslovnoga područja, ali i društveno-humanističkoga područja. Tako se u kurikulumu Povijesti (MZO, 2019b) održivi razvoj realizira na sadržajima o utjecaju čovjeka na okoliš u prošlosti i sadašnjosti, u kurikulumu Sociologije (MZO, 2019c) kroz upoznavanje učenika s tehnološkim i društveno proizvedenim rizicima i posljedicama djelovanja brojnih čimbenika na život pojedinca i društva, u kurikulumu Etike (MZO, 2019d) implementacijom tema ekološke etike, u kurikulumu Katoličkog vjeronauka (MZO, 2019e) odgovornim ponašanjem prema stvorenom svijetu, a u kurikulumu Politike i gospodarstva (MZO, 2019f) ukazujući na to kako potreba društva za napretkom dolazi uz korištenje ograničenih izvora. Usporedba s prirodoslovnim područjem pokazuje snažnu interdisciplinarnu povezanost međupredmetne teme s kurikulumom nastavnog predmeta Biologije (MZO, 2019g). Gotovo svi ciljevi učenja i poučavanja Biologije imaju poveznicu s ciljevima poučavanja međupredmetne teme Održivi razvoj, što se može uočiti usporedbom odgojno-obrazovnih ishoda Biologije s odgojno-obrazovnim očekivanjima Održivog razvoja na razini ciklusa i razreda.

Iako je većina zemalja prihvatila model međupredmetnog poučavanja održivog razvoja, rezultati istraživanja pokazuju različitu uspješnost implementacije propisanih sadržaja u okviru pojedinog predmeta. U Norveškoj, koja od 1970. godine u kurikulumu sadrži aktivnosti koje promoviraju zaštitu okoliša, implementacija u nastavi Geografije nije zadovoljavajuća (Sætre, 2016). S druge strane, njemački kurikulum mnogo je bolje strukturiran pa su definirane jasne smjernice za implementaciju sadržaja održivog razvoja u svakom pojedinom nastavnom predmetu, osim prirodoslovlja gdje su propisane zajedničke smjernice za biologiju, kemiju i fiziku. 
Ako se usporede sadržaji kurikuluma na međunarodnoj razini, uočava se da prevladavajući sustav vrijednosti svake zemlje ima utjecaja na odabir tema i pristup poučavanju. Za razliku od hrvatskog kurikuluma u kojemu prevladavaju sociokulturne teme, u slovenskom se ističe holistički pristup uz kritički pristup postojećem razvoju, dok je kurikulum Njemačke više usmjeren na istraživačke aktivnosti (Katunarić, 2017). Također, usporedba kurikuluma Kine i Norveške otkriva kako liberalnija Norveška kroz kurikulumske aktivnosti potiče individualizam pojedinca i veću samostalnost $\mathrm{u}$ odnosu na kineski model u kojemu je prikazana drugačija perspektiva odnosa prema obitelji, lokalnoj zajednici i koja podrazumijeva veću podršku nastavnika u procesu učenja (Li et al., 2019).

Većina kritika sadržaja hrvatskog kurikuluma međupredmetne teme Održivi razvoj ide u smjeru veće međupredmetne povezanosti, kako među predmetima istog razreda tako i kroz čitavu vertikalu (Hrgović, 2019). Osim toga, ne postoji povezanost formalnog i neformalnog obrazovanja, a veliki problem predstavljaju razlike u pristupima učitelja što otežava praćenje realizacije i evaluaciju na individualnoj razini i razini cijeloga razreda (Radeka, 2017, 165). S druge strane, ne smije se zanemariti i pozitivna strana ovoga kurikuluma koja se očituje u poticanju fleksibilnosti pri odabiru primjera. Nastavnik će, osluškujući interese i uz uvažavanje prethodnih znanja i iskustava, usmjeriti učenike ka rješavanju problema iz njihova neposredna okruženja. Tako učenje postaje autentično jer se temelji na vlastitom iskustvu, uz razumijevanje procesa kojima se dolazi do odgovarajućih rješenja i odluka.

\subsection{Izbor strategija učenja i poučavanja}

Ciljevi učenja i poučavanja kurikuluma međupredmetne teme Održivi razvoj upućuju na osmišljavanje poučavanja koje će na kreativan i zanimljiv način potaknuti učenike na promišljanje i stjecanje znanja, oblikovanje stavova i sustava vrijednosti te usvajanje ponašanja u skladu s održivim razvojem. Smjernice za realizaciju međupredmetne teme Održivi razvoj nalaze su u kurikulumu Geografije, Biologije, Kemije, Povijesti i drugih predmeta, a zajednički fokus je na razvoju kompetencija kao što su: pretraživanje i korištenje različitih izvora i vrsta informacija, rješavanje problemskih situacija, argumentiranje vlastitih 
stavova, primjena tehnika komunikacije i prezentiranja, rad u interaktivnome i multimedijskome okružju te rad na istraživačkim projektima.

Sasvim je jasno da razvoj navedenih kompetencija implicira korištenje suvremenih strategija učenja i poučavanja pa Nenadić-Bilan navodi:

»Proces aktivnog učenja u nastavi održivog razvoja ohrabruje sudionike na: postavljanje kritičkih pitanja, pročišćavanje sustava vrijednosti, predviđanje pozitivne i održive budućnosti, sustavno mišljenje, odgovaranje putem primijenjenog učenja, istraživanje dijalektike između tradicije i inovacije.« (Tilbury, 2001, 29, prema Nenadić-Bilan, 2017, 47)

Iako neke aktivnosti mogu zahtijevati i manji angažman učenika te razredno okruženje, cilj je da učenik preuzme aktivnu ulogu u cijelom procesu. Tu se svakako mogu primijeniti iste strategije poučavanja koje naročito apostrofiraju kurikulumi predmeta prirodoslovnog i društvenohumanističkog područja. Izvođenjem različitih praktičnih aktivnosti ostvaruje se istraživačko učenje koje uz diskretno vodstvo nastavnika prelazi u učenje otkrivanjem što na kraju rezultira učenjem utemeljenom na iskustvu.

Premda se klasifikacija nastavnih strategija kojima se ostvaruje aktivno učenje razlikuje ovisno o autorima (Jelavić, 1998; Bognar, Matijević, 2002; Cindrić et al., 2010, Kostović-Vranješ, 2015), u nastavnoj praksi najčešće se navode problemska nastava, istraživačka nastava i projektna nastava. Njihova primjena ovisi o ciljevima učenja, o odgojnoobrazovnim ishodima/očekivanjima, o dobi učenika, broju učenika koji se uključuju i dr. Budući da je riječ o metodološki sličnim aktivnostima, ponekad je teško uočiti razlike između ova tri oblika učenja. Osim navedenih strategija, nužno je promovirati strategije kojima se potiče komunikacija među učenicima, posebice argumentiranje u kojem se sociokulturni kontekst suprotstavlja znanstvenim činjenicama. Finska, kao jedna od država s najkvalitetnijim obrazovanjem, prepoznala je važnost pedagogije i edukacijske psihologije te je razvila tri pedagoška modela koji služe kao smjernice nastavnicima kemije u implementaciji tema održivog razvoja (Juntunen, Aksela, 2014).

U hrvatskim okvirima najčešći način realizacije sadržaja održivog razvoja jest sudjelovanjem učenika u projektnim zadacima, kroz izvannastavne aktivnosti ili tijekom izvanučioničke nastave (Husanović-Pejnović, 2011; Mlinarević, Brust, 2009; Kostović-Vranješ et al., 
2016). Naravno, u školskom projektu naglasak ne smije biti na problemu i njegovom konačnom rješenju, nego na procesu kojim učenik/ učenici dolaze do rješenja. Iako se projektna nastava temelji na usvajanju znanstvene metode rada, projekti održivog razvoja imaju drugačiju svrhu. Njihova osnovna zadaća jest potaknuti kod učenika razvoj kritičkog mišljenja, sudjelovanje u raspravama te oblikovanje vlastitih stavova kako bi jednoga dana mogli samostalno donositi odluke na korist uže i šire lokalne zajednice. Prije početka svih projektnih aktivnosti važno je izraditi plan djelovanja. Poželjno je izdvojiti problem, postaviti ciljeve, odabrati članove tima i podijeliti uloge, odrediti vremenske rokove, odrediti način prezentacije i evaluacije. Analiza metodologije koja se koristi u razvoju školskih OOR projekata ukazuje na važnost praćenja svih etapa projekta. Za prikupljanje i analiziranje podataka mogu poslužiti: dnevnici (portfolio), foto izvješća, SWOT analiza, intervju, upitnik, metoda kratkog promišljanja, ispitivanje mišljenja pomoću kartica, grupna rasprava i promatranje sa sudjelovanjem (Ništ, Smojver, 2011, 67-87). U pojedinim etapama učenici se mogu koristiti različitim digitalnim alatima što je naročito korisno u obradi podataka i prezentaciji rezultata. Iako se prema posljednjim istraživanjima računalne i informacijske pismenosti hrvatskih učenika i nastavnika, $\mathrm{u}$ odnosu na ostale zemlje sudionice, $\mathrm{u}$ velikom broju kategorija $\mathrm{Hr}$ vatska nalazi na posljednjem mjestu (Roth et al., 2014), ne smije se zanemariti potencijal koji informacijska i komunikacijska tehnologija ima u ostvarivanju odgojno-obrazovnih očekivanja kurikuluma Održivi razvoj. Važno je istaknuti i činjenicu da se tijekom rada na projektu redovito ostvaruje povezanost i s međupredmetnim temama Učiti kako učiti, Zdravlje te Građanski odgoj i obrazovanje, čime projekt izlazi iz okvira početnog problema te služi kao sredstvo razvoja vrlo različitih kompetencija i kod učenika i nastavnika.

\subsection{Metode vrednovanja}

Kurikulum međupredmetne teme Održivi razvoj, osim smjernica koje se odnose na učenje i poučavanje, na kraju sadrži poglavlje vezano za vrednovanje. Ostvarenost odgojno-obrazovnih očekivanja vrednuje se u okviru nastavnih predmeta i u okviru kurikuluma škole, a vrednuje se razvoj: kritičkoga i kreativnoga mišljenja, osjećaja odgovornosti pre- 
ma okolišu, živome svijetu i budućim generacijama, osjećaja solidarnosti i spremnosti da se pomogne potrebitima u duhu pravednosti i opće dobrobiti te razvoj odgovarajućih vještina za djelovanje i aktivnoga odnosa prema održivome razvoju i područjima koja obuhvaća.

Nije jasno kako vrednovati razvoj kompetencija koje se odnose na vještine i stavove s obzirom da je riječ o specifičnim kompetencijama koje se ne mogu tako lako mjeriti i koje najvećim dijelom nisu nastale kao rezultat poučavanja. Drugi problem je svakako administrativne prirode, a tiče se praćenja realizacije međupredmetne teme kroz više predmeta. Sadržaji održivog razvoja trebali bi se vrednovati zajedno sa sadržajima predmeta koji mogu, ali i ne moraju, pripadati istom odgojno-obrazovnom području. Međupredmetnom vrednovanju treba prethoditi međupredmetno poučavanje koje u hrvatskim okvirima još nije zaživjelo. U Velikoj Britaniji se od devedesetih godina prošlog stoljeća uvode promjene nacionalnog kurikuluma pa tako za npr. međupredmetno poučavanje u prirodoslovnom području postoji stručna literatura u kojoj su opisani ključni koncepti, primjeri sadržaja koji se mogu korelirati i opis postupaka vrednovanja (Byrne, Brodie, 2011). Iako je Hrvatska u NOK-u apostrofirala važnost sedam odgojno-obrazovnih područja, u istom dokumentu nisu izdvojeni zajednički sadržaji niti je razrađena metodologija praćenja napretka učenika u svakom pojedinom odgojno-obrazovnom području. Premda se u kurikulumu međupredmetne teme Održivi razvoj navodi važnost izvješćivanja učenika i roditelja o aktivnostima učenika, konkretnih smjernica nema te je ova obaveza prepuštena autonomiji svake škole.

Svako vrednovanje, pa tako i vrednovanje odgojno-obrazovnih očekivanja međupredmetne teme, nastavnik treba pažljivo planirati. Ovisno o sadržaju, odnosno odgojno-obrazovnim očekivanjima pojedinog ciklusa, nastavnik odabire metode, a sve prikupljene dokaze trebao bi pohraniti u učeničku mapu (portfolio). Naglasak je na formativnom vrednovanju pa bi se nastavnik trebao odlučiti za neke od aktivnosti pristupa vrednovanje za učenje i vrednovanje kao učenje. Prema Morrisonu (2017), pri vrednovanju međupredmetnih tema trebalo bi uzeti u obzir deset čimbenika, a to su: što vrednovati, kako integrirati aktivnosti vrednovanja u kurikulum svoga predmeta, kada i koliko često vrednovati, kako postići valjanost i pouzdanost vrednovanja, koje postupke odabrati, kako prikupiti dokaze, kako ukloniti sve ometajuće faktore 
koji mogu umanjit pouzdanost, kako odrediti kriterije vrednovanja, kako pratiti rad učenika za vrijeme vrednovanja i kako predstaviti rezultate vrednovanja.

\section{Zaključak}

Održivi razvoj kao koncept koji je usmjeren stvaranju demokratskog ekonomski održivog okruženja u kojemu svaki pojedinac živi u skladu s prirodom više nije utopija, već naša stvarnost. U međuvremenu su pokrenute brojne inicijative koje su rezultirale donošenjem Strategije održivog razvitka Republike Hrvatske kao zakonodavnog okvira koji će olakšati provedbu načela održivog razvoja u hrvatskom odgojno-obrazovnom sustavu. Iako je uvođenje međupredmetne teme Održivi razvoj školske godine 2019./2020. pozitivan pomak u kontekstu odgoja i obrazovanja za održivi razvoj, brojne su prepreke u realizaciji novoga kurikuluma. Pred nastavnike se stavlja velika zadaća jer trebaju osposobiti mlade ljude za ulogu aktivnih građana koji će imati dovoljno znanja i vještina suočiti se sa svim nepoznanicama koje donosi 21. stoljeće. Naime, istraživanja pokazuju da je za realizaciju odgojno-obrazovnih očekivanja iz kurikuluma Održivog razvoja potreban daleko širi spektar znanja i vještina od onih koje je nastavnik stekao formalnim obrazovanjem. Osim poznavanja sadržaja više različitih predmetnih kurikuluma i međupredmetnih tema, nastavniku su potrebne didaktičko-metodičke smjernice koje se odnose na izbor sadržaja, korištenje strategija učenja i poučavanja te vrednovanje. Naime, sadržaji ovog kurikuluma ne mogu se ostvariti na tradicionalan način, bez interdisciplinarnog pristupa i uvažavanja različitih potreba i sposobnosti učenika. Kako se realizacija ne bi svela na samo pojedine nastavnike i škole, restrukturiranje treba započeti s promjenama u visokom školstvu. Što se tiče sadržaja donesenog kurikuluma, u budućnosti se može očekivati da će se, u skladu s promjenama na globalnoj razini, sadržaji kurikuluma nadopunjavati i mijenjati kako bi zadržali svoju aktualnost i svrsishodnost. 


\section{Literatura}

Bognar, Ladislav; Matijević Milan (2002), Didaktika, Zagreb: Školska knjiga.

Borić, Edita; Jindra, Ranka; Škugor, Alma (2008), »Razumijevanje i primjena sadržaja cjeloživotnog učenja za održivi razvoj«, Odgojne znanosti, 10(2), str. 315-327.

[BMZ] German Federal Ministry of Economic Cooperation and Development (2016), Curriculum framework, Education for Sustainable devlopment. Dostupno na: https://www.globaleslernen.de/sites/default/files/files/link-elements/curriculum framework_education_for_sustainable development barrierefrei.pdf [21.8. 2020.]

Byrne, Eleanor; Brody, Marilyn (2011), Cross Curricural Teaching and Learning in Secondary School, Science, London and New York: Routledge.

Cindrić, Mijo; Miljković, Dubravka; Strugar, Vladimir (2010), Didaktika i kurikulum, Zagreb: IEP-D2.

De Zan, Ivan (2000), »Obrazovanje i odgoj za okoliš«, Napredak, 141(3), str. 328339. Dostupno na: https://www.bib.irb.hr/190786 [13. 7. 2020.]

[EU] European Union (2008), The European Qualifications Framework for Lifelong Learning (EQF). Dostupno na: http://ecahe.eu/w/images/3/34/EQF.pdf [13. 7. 2020.]

Garašić, Diana (2011), »Uvodno o održivom razvoju«, »UN-ovo desetljeće obrazovanja za održivi razvoj«, »Nastavničke kompetencije važne za OOR«, u: Mićanović, Miroslav (ur.), Obrazovanje za održivi razvoj - priručnik za osnovne i srednje škole, Zagreb: Agencija za odgoj i obrazovanje, str. 13-61.

Horvat, Jelena (2018), Zastupljenost tema iz zaštite prirode i okoliša u nastavi prirode $i$ biologije, diplomski rad, Sveučilište Josipa Jurja Strossmayera u Osijeku. Dostupno na: https://core.ac.uk/download/pdf/197872747.pdf [13. 7. 2020.]

Hrgović, Ivana (2019), Međupredmetna tema Održivi razvoj u odgojno-obrazovnom sustavu Republike Hrvatske, diplomski rad, Prirodoslovno-matematički fakultet, Sveučilište u Zagrebu. Dostupno na: https://repozitorij.pmf.unizg.hr/ islandora/object/pmf\%3A6153/datastream/PDF/view [13. 7. 2020.]

Husanović-Pejnović, Dragica (2011), Održivi razvoj i izvanučionička nastava u zavičaju, Zagreb: Školska knjiga.

Jelavić, Filip (1998), Didaktika, Jastrebarsko: Naklada Slap.

Juntunen, Marianne K.; Aksela, Maija K. (2014), »Education for sustainable development in chemistry - Challenges, possibilities and pedagogical models in Finland and elsewhere «, Chemistry Education Research and Practice, 15, str. 488-500. doi: https://doi.org/10.1039/C4RP00128A

Katunarić, Vjeran (2017), »Održivi razvoj Hrvatske - Odgovornost, ravnoteža, participacija, kurikulum«, u: Radeka, Igor (ur.), Održivi razvoj i odgojno-obrazovni sustav Hrvatske: znanstveno-stručni skup, zbornik radova, Zadar: Sveučilište u Zadru, Dječji vrtić Radost, str. 27-41. 
Kolar, Ana (2019), Kompetentnost učitelja i nastavnika za razvoj prirodoslovne pismenosti učenika, diplomski rad, Sveučilište Josipa Jurja Strossmayera u Osijeku. Dostupno na: https://zir.nsk.hr/islandora/object/bioos\%3A377 [13. 7. 2020.]

Kostović-Vranješ, Vesna; Bulić, Mila; Novoselić, Danijela (2016), »Izvannastavna aktivnost kompostiranje u promicanju obrazovanja za održivi razvoj«, Školski vjesnik: časopis za pedagogijsku teoriju i praksu, 65, str. 79-990.

Kostović-Vranješ, Vesna (2015), Metodika nastave predmeta prirodoslovnog područja, Zagreb: Školska knjiga.

Kostović-Vranješ, Vesna (2016), »Inicijalno obrazovanje i profesionalno usavršavanje učitelja usmjereno prema osposobljavanju za promicanje obrazovanja za održivi razvoj«, Zbornik radova Filozofskog fakulteta u Splitu, 6-7, str. 166-188.

Laurie, Robert; Nonoyama-Tarumi, Yuko; Mckeown, Rosalyn; Hopkins, Charles (2016), »Contributions of education for sustainable development (ESD) to quality education: A synthesis of research», Journal of Education for Sustainable Development, 10(2), str. 226-242. doi: https://doi.or$\mathrm{g} / 10.1177 \% 2 \mathrm{~F} 0973408216661442$

Li, Minyi; Zhang, Yulin; Yuan, Lehan; Birkeland, Asta (2019), »A critical analysis of education for sustainability in early childhood curriculum documents in China and Norway«, ECNU Review of Education, 2(4), str. 441-457. doi: https://doi.org/10.1177\%2F2096531119893483

Miočić, Marijana (2017), »Implementacija održivog razvoja u kurikulum ranog i predškolskog odgoja«, u: Radeka, Igor (ur.), Održivi razvoj i odgojno-obrazovni sustav Hrvatske: znanstveno-stručni skup, zbornik radova, Zadar: Sveučilište u Zadru, Dječji vrtić Radost, str. 123-133.

Mlinarević, Vesnica; Brust, Maja (2009), »Kvaliteta provedbe školskih izvannastavnih aktivnosti«, u: Majorosi, Imre (ur.), Tehetseg Nap: Az eljárás / III. Dan talenata: zbornik radova / The 3rd talented pupils day: Proceedings, Kanjiža: Bolyai Farkas Alapitvany, str. 25-32. Dostupno na: https://www. bib.irb.hr/481572 [13. 7. 2020.]

Morrison, Keith (2017), Implementing Cross-Curricular Themes, London and New York: Routledge.

Mróz, Anna; Tomczyk, Łukasz (2018), »Teachers' knowledge on education for sustainable development - Polish context«, Croatian Journal of Education, 20(3), str. 1001-1028. doi: https://doi.org/10.15516/cje.v20i3.3252

[MZOŠ] Ministarstvo znanosti, obrazovanja i športa RH (2006), Nastavni plan i program za osnovnu školu, Zagreb: Ministarstvo znanosti, obrazovanja i športa RH. Dostupno na: https://www.azoo.hr/images/AZOO/Ravnatelji/ RM/Nastavni_plan_i_program_za_osnovnu_skolu_-_MZOS_2006_pdf $[21$. 8. 2020.]

[MZOS] Ministarstvo znanosti, obrazovanja i sporta RH (2010), Nacionalni okvirni kurikulum za predškolski odgoj i obrazovanje te opće obvezno i srednjoškolsko obrazovanje, Zagreb: Ministarstvo znanosti obrazovanja i sporta 
RH. Dostupno na: https://www.azoo.hr/images/stories/dokumenti/Nacionalni_okvirni kurikulum.pdf [15. 8. 2020.]

[MZOS] Ministarstvo znanosti, obrazovanja i sporta RH (2012), Kurikulum građanskog odgoja i obrazovanja. Dostupno na: https://www.azoo.hr/images/ Kurikulum gradanskog_odgoja_i obrazovanja.pdf [15. 8. 2020.]

[MZO] Ministarstvo znanosti i obrazovanja (2019), Odluka o donošenju kurikuluma za međupredmetnu temu Održivi razvoj za osnovne i srednje škole u Republici Hrvatskoj. Dostupno na: https://narodne-novine.nn.hr/clanci/sluzbeni/2019 $01 \_7$ 152.html [15.8. 2020.]

[MZO] Ministarstvo znanosti i obrazovanja (2019a), Odluka o donošenju kurikuluma za nastavni predmet Geografije za osnovne škole i gimnazije u Republici Hrvatskoj. Dostupno na: https://narodne-novine.nn.hr/clanci/sluzbeni/2019_01_7_145.html [15.8.2020.]

[MZO] Ministarstvo znanosti i obrazovanja (2019b), Odluka o donošenju kurikuluma za nastavni predmet Povijesti za osnovne škole i gimnazije u Republici Hrvatskoj. Dostupno na: https://narodne-novine.nn.hr/clanci/sluzbeni/2019_03_27_557.html [15.8. 2020.]

[MZO] Ministarstvo znanosti i obrazovanja (2019c), Odluka o donošenju kurikuluma za nastavni predmet Sociologije za gimnazije u Republici Hrvatskoj. Dostupno na: https://narodne-novine.nn.hr/clanci/sluzbeni/201901 7160. $\underline{\mathrm{html}}[20.9 .2020$.

[MZO] Ministarstvo znanosti i obrazovanja (2019d), Odluka o donošenju kurikuluma za nastavni predmet Etike za gimnazije u Republici Hrvatskoj. Dostupno na: https://narodne-novine.nn.hr/clanci/sluzbeni/2019 $01 \quad 10 \quad 207 . h t m l$ [20. 9. 2020.]

[MZO] Ministarstvo znanosti i obrazovanja (2019e), Odluka o donošenju kurikuluma za nastavni predmet Katolički vjeronauk za osnovne škole i gimnazije u Republici Hrvatskoj. Dostupno na: https://narodne-novine.nn.hr/clanci/sluzbeni/2019_01_10_216.html [20.9. 2020.]

[MZO] Ministarstvo znanosti i obrazovanja (2019f),Odluka o donošenju kurikuluma za nastavni predmet Politike $i$ gospodarstva za gimnazije u Republici Hrvatskoj. Dostupno na: https://narodne-novine.nn.hr/clanci/sluzbeni/201901 7 159.html [20.9. 2020.]

[MZO] Ministarstvo znanosti i obrazovanja (2019g), Odluka o donošenju kurikuluma za nastavni predmet Biologije za osnovne škole i gimnazije u Republici Hrvatskoj. Dostupno na: https://narodne-novine.nn.hr/clanci/sluzbeni/201901 7 149.html [20.9. 2020.]

Nenadić-Bilan, Diana (2017), »Odgoj i obrazovanje za održivi razvoj - Prošlost, sadašnjost budućnost«, u: Radeka, Igor (ur.), Održivi razvoj i odgojno-obrazovni sustav Hrvatske: znanstveno-stručni skup, zbornik radova, Zadar: Sveučilište u Zadru, Dječji vrtić Radost, str. 41-53.

Ništ Marina; Smojver Borjanka (2011), »Metodologija korištena u razvoju školskih OOR-projekata«, u: Mićanović, Miroslav (ur.), Obrazovanje za održivi 
razvoj - Priručnik za osnovne i srednje škole, Zagreb: Agencija za odgoj i obrazovanje, str. 65-87.

[NN] Narodne novine (2009), Strategija održivog razvitka Republike Hrvatske. Dostupno na: https://narodne-novine.nn.hr/clanci/sluzbeni/2009 $03 \quad 30658$. html [13. 9. 2020.]

[NN] Narodne novine (2019), Kurikulum međupredmetne teme Održivi razvoj za osnovne i srednje škole. Dostupno na: https://narodne-novine.nn.hr/clanci/ sluzbeni/2019_01_7_152.html [13.9. 2020.]

Previšić, Vlatko (2008), »Globalne dimenzije održiva razvoja u nacionalnom školskom kurikulumu«, u: Uzelac, Vinka; Vujičić, Lidija (ur.), Cjeloživotno učenje za održivi razvoj, Rijeka: Učiteljski fakultet u Rijeci.

Radeka, Igor (2017), »Održivi razvoj u nastavnom planu i programu i reformskim kurikulumima za osnovnu školu«, u: Radeka, Igor (ur.), Održivi razvoj i odgojno-obrazovni sustav Hrvatske: znanstveno-stručni skup, zbornik radova, Zadar: Sveučilište u Zadru, Dječji vrtić Radost, str. 159-168.

Roth, Michele. B.; Markočić-Dekanić, Ana; Ružić, Danica (2014), »ICILS 2013 Priprema za život u digitalnom dobu«, Zagreb: Nacionalni centar za vanjsko vrednovanje - PISA centar. Dostupno na: https://www.ncvvo.hr/medunarodna-istrazivanja/icils/ [13.7.2020.]

Sætre, Per J.(2016), »Education for sustainable development in Norwegian Geography curricula«, Nordidactica - Journal of Humanities and Social Science Education, 1, str. 63-78. Dostupno na: https://www.diva-portal.org/smash/ get/diva2:1047515/FULLTEXT01.pdf [13. 7. 2020.]

Tatković, Nevenka; Diković, Marina; Štifanić, Mauro (2015), »Odgoj i obrazovanje za razvoj danas i sutra: Ekološke i društvene paradigme«, Pula: Sveučilište Jurja Dobrile u Puli. Dostupno na: https://www.bib.irb.hr/802025 [13. 7. 2020.]

[UN] United Nations (2015), Transforming our world: The 2030 Agenda for sustainable development. Dostupno na: https://sustainabledevelopment.un.org/ content/documents $/ 21252030 \% 20$ Agenda $\% 20$ for $\% 20$ Sustainable $\% 20$ Development $\% 20$ web.pdfdevelopment [13.8.2020.]

[UNESCO] United Nations Educational, Scientific and Cultural Organization (2005), Promotion of a Global Partnership for the UN Decade of Education for Sustainable development (2005 - 2014), New York. Dostupno na: https:// unesdoc.unesco.org/ark:/48223/pf0000141629 [13. 7. 2020.]

Uzelac, Vinka; Lepičnik-Vodopivec, Jurka; Anđić, Dunja (2014), Djeca - odgoj i obrazovanje - održivi razvoj / U potrazi za novim perspektivama razvoja odgoja i obrazovanja djece za održivi razvoj, Zagreb: Golden marketing Tehnička knjiga.

Uzelac, Vinka; Starčević Irena (1999), Djeca i okoliš, Rijeka: Adamić.

Vinković, Anamarija (2018), Uloga budućih nastavnika u promicanju održivog razvoja u obrazovanju, diplomski rad, Rijeka: Sveučilište u Rijeci, Filozofski fakultet u Rijeci. Dostupno na: https://zir.nsk.hr/islandora/object/ ffri\%3A1110 [23. 7. 2020.] 
Vukelić, Nena (2020), »Odrednice spremnosti (budućih) nastavnika na obrazovanje za održivi razvoj«, Napredak, 161(1-2), str. 141-161.

Vukobratović, Jelena (2017), Stavovi učitelja o položaju i mogućnostima implementacije odgoja i obrazovanja za održivi razvoj u osnovne škole, diplomski rad, Rijeka: Sveučilište u Rijeci, Filozofski fakultet u Rijeci. Dostupno na: https://zir.nsk.hr/islandora/object/ffri\%3A1122 [23. 7. 2020.]

\title{
DIDACTIC GUIDELINES FOR IMPLEMENTATION OF THE CROSS-CURRICULAR TOPIC "SUSTAINABLE DEVELOPMENT" IN CURRICULA
}

\author{
Gabrijela Marin
}

Sustainable development - as a concept of changes directed at creating an environment in which a person lives in harmony with nature - is nowadays an imperative. Laws and regulations concerning sustainable development exist, but the implementation of related topics in curricula is sporadic, led by few teachers sensible to eco-topics, and realized mainly through specific project activities. Even though the curricular reform in Croatia recognized the importance of sustainable development and introduced the cross-curricular topic devoted to it, the realization of related educational goals is questionable. The conceptual complexity of the new curriculum that is based on interdisciplinarity presupposes knowledge and skills that go beyond those provided to future teachers during their formal education. The aim of this paper is to present the most important moments in the history of education for sustainable development in Croatia. Further, based on the research by different authors, we shall present didactic guidelines (including content, strategies of learning and teaching, and evaluation) that can help teachers with implementation of the new curriculum.

Keywords: sustainable development, education for sustainable development (ESD), teachers' competencies, strategies of learning and teaching, cross-curricular topics

Prilog 1. Popis obveznih i preporučenih sadržaja iz kurikuluma međupredmetne teme Održivi razvoj (MZO, 2019)

1. ciklus Obvezni: zajednica, međuljudski odnosi i razlike, raznolikost u prirodi, povezanost boravka u prirodi i zdravlja, zaštita okoliša i prirode, ušteda energije, priprema komposta, recikliranje odnos čovjeka prema prirodi, odnos prema životinjama, obiteljski i međuljudski odnosi, nenasilno rješavanje sukoba; preporučeni: 
školski izleti u prirodu, ekosela i imanja, uzgoj zdrave hrane, crtanje i umjetničko izražavanje, igra i zabava, školski vrtovi, izravna komunikacija, empatija.

2. ciklus Obvezni: obnovljivi i neobnovljivi izvori energije, prirodni resursi, ljudski utjecaj na prirodu, međudjelovanje u prirodi, zdrava hrana, gospodarenje otpadom, mogućnosti uštede energije, društvena (ne)pravda, solidarnost, ljudska prava, osobna i opća dobrobit, prava životinja, (ne)zagađeni okoliš (voda, zrak, tlo), otpad,; preporučeni: izvori energije i podneblje, termički izolatori, školski vrtovi, IKT alati za djelovanje u korist održivoga razvoja - GLOBE, zeleni izleti, školske zadruge, suradnja, kreativnost, edukativne vježbe, potrošnja, potrošačko društvo, zelena proizvodnja, buka, svjetlosno zagađenje, pesticidi i umjetna gnojiva.

3. ciklus Obvezni: klimatske promjene, efekt staklenika i globalno zatopljenje, kisele kiše, ozonske rupe, bioraznolikost, vrijednosti ekosustava, analiza prirodne raznolikosti i prepoznavanje »vruće točke«, ekološki otisak i utjecaj socijalnih razlika na održivost, volontiranje i građanski aktivizam, globalne promjene i procesi, kritičko mišljenje, solidarnost i ravnopravnost, permakultura, istraživačko učenje okolišnih, društvenih, ekonomskih čimbenika, integrirani i održivi energija, hrana i promet, primjeri održivog dizajna, preporučeni: prepoznavanje lokalnih resursa za održivi razvoj, osnivanje zadruga, upoznavanje sa zakonima i ugovorima o očuvanju okoliša te o temama koje održivi razvoj pokriva (dokumenti povezani s problemom koji je uočen i traži rješenje), osnivanje skupina dežurnih ekopatrola i sl., čimbenici dobrobiti, klimatska pravda, napredni i novi ekonomski razvojni modeli, ograničenje prirodnih resursa, društvena pravda, socijalne politike, politički sustav, demokracija, kreiranje politika i politički sustavi.

4. ciklus Obvezni: utjecaj ljudi i gospodarstva na održivi razvoj, ekonomske politike, klimatska pravda, načela održivoga razvoja, volontiranje, globalne promjene i procesi (klimatske promjene, elementarne nepogode), proizvodnja hrane i, socijalna pravda, ekološki otisak, održivo korištenje resursa, gospodarenje otpadom, integrirani i održivi energija, hrana i promet, primjeri održivog dizajna, granica ograničenja prirodnih resursa, solidarnost, kvaliteta života, javne politike, indeksi društvenoga razvoja (ili pokazatelji društvenoga razvoja), globalne politike, resursi, ekološki otisak; preporučeni: prirodna ravnoteža, kvaliteta života, ekosustav, stanište, resursi, 
biljne vrste, gospodarstvo, politički sustavi, društveno poduzetništvo, zadruge, solidarnost i ravnopravnost, inovativna rješenja - plava ekonomija, ekološko modeliranje, djelovanje prema rješavanju problema, modeli aktivnoga djelovanja, urbana permakultura, niskougljični razvoj Hrvatske, napredni i novi ekonomski razvojni modeli, sigurnost, ne(zagađeni) okoliš.

5. ciklus Obvezni: klimatske promjene, utjecaji na okoliš, ekološki otisak, održiva proizvodnja i potrošnja, načela održive proizvodnje i potrošnje, politički i ekonomski sustavi, klimatska pravda, volontiranje, djelovanje usmjereno prema budućnosti, primjeri održivog dizajna, obvezni resursi, granica raspoloživosti prirodnih resursa, ekološki otisak ravnoteža i kvaliteta ekosustava, volontiranje, zdrava ishrana i proizvodnja hrane, globalne politike prema okolišu i socijalnim pitanjima; preporučeni: tradicionalna proizvodnja, društveno poduzetništvo, zadruge, građanski aktivizam, globalne promjene i procesi, zakoni i ugovori o očuvanju okoliša i o temama koje održivi razvoj pokriva, solidarnost i ravnopravnost, permakultura - održivo dizajniranje životnih prostora, niskougljični razvoj Hrvatske, energetska učinkovitost. 